\title{
Effect of a whitlockite glass-ceramic on the occlusion of dentinal tubules for dentin
}

\section{hypersensitivity treatment}

\author{
Efeito de um vitrocerâmico de whitlockite na oclusão dos túlbullos dentinários para tratamento dla \\ hipersensibilidade dentinária
}

Efecto de una vitrocerámica whitlockita sobre la oclusión de los túbulos dentinarios para el tratamiento de la hipersensibilidad dentinaria

Received: 02/20/2021 | Reviewed: 02/27/2021 | Accept: 03/04/2021 | Published: 03/12/2021

\author{
Amanda de Castro Juraski \\ ORCID: https://orcid.org/0000-0003-3998-3414 \\ Federal University of ABC, Brazil \\ E-mail: amanda.juraski@gmail.com \\ Daniela Casimiro Figueredo \\ ORCID: https://orcid.org/0000-0002-1778-9875 \\ Federal University of ABC, Brazil \\ E-mail: danielacfigueredo@gmail.com \\ Nasser Ali Daghastanli \\ ORCID: https://orcid.org/0000-0003-4048-1286 \\ Federal University of ABC, Brazil \\ E-mail: nasser.daghastanli@ufabc.edu.br \\ Claudinei dos Santos \\ ORCID: https://orcid.org/0000-0002-9398-0639 \\ State University of Rio de Janeiro, Brazil \\ E-mail: claudinei@ pesquisador.cnpq.br \\ Maria Helena Vaz Fernandes \\ ORCID: https://orcid.org/0000-0002-1240-2512 \\ University of Aveiro, Portugal \\ E-mail: helena.fernandes@ua.pt \\ Patrícia Aparecida da Ana \\ ORCID: https://orcid.org/0000-0003-2857-7517 \\ Federal University of ABC, Brazil \\ E-mail: patricia.ana@ufabc.edu.br \\ Juliana Kelmy Macário Barboza Daguano \\ ORCID: https://orcid.org/0000-0001-6098-6826 \\ Federal University of ABC, Brazil \\ E-mail: juliana.daguano@ufabc.edu.br
}

\begin{abstract}
Dentin hypersensitivity (DH) is characterized by short and sharp pain in response to external stimuli and can be treated by occluding dentinal tubules. In this study, a whitlockite (Mg-substituted tricalcium phosphate phase) glassceramic based on the $3 \mathrm{CaO} . \mathrm{P}_{2} \mathrm{O}_{5}-\mathrm{SiO}_{2}-\mathrm{MgO}$-system and its parent glass were evaluated on their effectiveness in treating DH. A bioactive glass with nominal composition 52.75(3CaO. $\left.\mathrm{P}_{2} \mathrm{O}_{5}\right)-30 \mathrm{SiO}_{2}-17.25 \mathrm{MgO}$ (wt.\%) was doublestage heat-treated at $700{ }^{\circ} \mathrm{C}$ and $775^{\circ} \mathrm{C}$ for $4 \mathrm{~h}$. Therefore, third molar human teeth were demineralized and randomly distributed into groups: NT - negative control (no treatment), BG - positive control (treated with Bioglass@45S5), GL - treatment with parent glass, and WGC - treatment with whitlockite glass-ceramic. Then, all the dentin samples were immersed in artificial saliva and stored for 7 days at $37^{\circ} \mathrm{C}$. The biomaterials were evaluated by X-ray Diffraction (XRD) and Scanning Electron Microscopy (SEM). The dentin samples were analyzed by ATR-FTIR, to identify and quantify compositional variations on dentin surface, and by SEM. XRD identified whitlockite as the crystalline phase of GC and its presence leads to the formation of blunt particles, as shown by SEM images. ATR-FTIR analysis confirmed the formation of apatite compounds on the surface of all sample from BG, GL and WGC which was corroborated by the occlusion of dentinal tubules, as demonstrated by SEM images. Furthermore, the relative infrared peak intensities were compared statistically. Regarding surface reactivity by the semi-quantitative FTIR analysis, whitlockite GC demonstrated similarity to Bioglass®45S5 indicating that this material is promising for treating DH.

Keywords: Biomaterials; Bioactive glass-ceramic; $3 \mathrm{CaO} . \mathrm{P}_{2} \mathrm{O}_{5}-\mathrm{SiO}_{2}-\mathrm{MgO}$-system; Dentin remineralization; Dentin hypersensitivity.
\end{abstract}




\title{
Resumo
}

A hipersensibilidade dentinária (HD) é caracterizada pela dor curta e aguda em resposta a estímulos externos, podendo ser tratada pela oclusão dos túbulos dentinários. Neste estudo, vidro original e uma vitrocerâmica do sistema $3 \mathrm{CaO} . \mathrm{P}_{2} \mathrm{O}_{5}-\mathrm{SiO}_{2}-\mathrm{MgO}$ contendo whitlockita (fase de fosfato tricálcico substituído com $\mathrm{Mg}$ ) foram avaliados quanto à eficácia no tratamento da $\mathrm{HD}$. Um vidro bioativo com composição 52,75.(3CaO. $\left.\mathrm{P}_{2} \mathrm{O}_{5}\right)-30 \mathrm{SiO}_{2}-17,25 \mathrm{MgO}(\% \mathrm{p})$ foi tratado termicamente a $700^{\circ} \mathrm{C}$ e $775^{\circ} \mathrm{C}$ por $4 \mathrm{~h}$. Terceiros molares humanos foram desmineralizados e distribuídos aleatoriamente em grupos: NT - controle negativo (sem tratamento), BG - controle positivo (tratado com Bioglass $\left.{ }^{\circledR} 45 \mathrm{~S} 5\right)$, GL - tratamento com vidro original e WGC - tratamento com whitlockita. Em seguida, amostras de dentina foram imersas em saliva artificial e armazenadas por 7 dias a $37^{\circ} \mathrm{C}$. Os biomateriais foram avaliados por Difração de Raios X (XRD) e Microscopia Eletrônica de Varredura (MEV). As amostras de dentina foram analisadas por MEV e ATR-FTIR, para identificar e quantificar variações composicionais na superfície dentinária. Foi identificada whitlockita como fase cristalina do GC, e sua presença leva à formação de partículas arredondadas, conforme mostrado por imagens de MEV. A análise de ATR-FTIR confirmou a formação de apatita na superfície de amostras BG, GL e WGC, o que foi corroborado pela oclusão dos túbulos dentinários, conforme imagens em MEV. As intensidades dos picos de infravermelho foram comparadas estatisticamente. Em relação à reatividade superficial pela análise semiquantitativa de FTIR, o GC demonstrou similaridade com o Bioglass $₫ 45 S 5$ indicando que este material é promissor no tratamento de HD.

Palavras-chave: Biomateriais; Vitrocerâmica bioativa; Sistema $3 \mathrm{CaO} . \mathrm{P}_{2} \mathrm{O}_{5}-\mathrm{SiO}_{2}-\mathrm{MgO}$; Remineralização da dentina; Hipersensibilidade dentinária.

\begin{abstract}
Resumen
Hipersensibilidad Dentinaria (HD) se caracteriza por un dolor breve y agudo en respuesta a estímulos externos y se puede tratar ocluyendo los túbulos dentinarios. En este estudio, se evaluó la eficacia de una vitrocerámica whitlockita (fase de fosfato tricálcico sustituido con $\mathrm{Mg}$ ) basada en el sistema $3 \mathrm{CaO}_{2} \mathrm{P}_{2} \mathrm{O}_{5}-\mathrm{SiO}_{2}-\mathrm{MgO}$ y su vidrio en el tratamiento de $\mathrm{HD}$. Un vidrio bioactivo 52,75. $\left(3 \mathrm{CaO} . \mathrm{P}_{2} \mathrm{O}_{5}\right)-30 \mathrm{SiO}_{2}-17,25 . \mathrm{MgO}$ (\%peso) se trató térmicamente a $700^{\circ} \mathrm{C}$ y $775^{\circ} \mathrm{C} / 4 \mathrm{~h}$. Dientes del tercer molar humano fueron desmineralizados y distribuidos aleatoriamente en grupos: NT control negativo (sin tratamiento), GB - control positivo (tratado con Bioglass®45S5), GL - tratamiento con vidrio parental y WGC - tratamiento con vitrocerámica whitlockita. Las muestras de dentina se sumergieron en saliva artificial y se almacenaron durante 7 días a $37^{\circ} \mathrm{C}$. Los biomateriales se evaluaron mediante difracción de rayos $\mathrm{X}$ (DRX) y microscopía electrónica de barrido (MEB). Las muestras de dentina fueron analizadas por ATR-FTIR y por MEB. XRD identificó la whitlockita como la fase cristalina de GC y su presencia conduce a la formación de partículas romas, como se muestra en las imágenes. ATR-FTIR confirmó compuestos de apatita en todas las muestras de BG, GL y WGC, lo que fue corroborado por la oclusión de los túbulos dentinarios, en las imágenes MEB. Además, las intensidades relativas de los picos infrarrojos se compararon estadísticamente. Con respecto a la reactividad de la superficie mediante el análisis FTIR semicuantitativo, whitlockita GC demostró similitud con Bioglass®45S5, lo que indica que este material es prometedor para el tratamiento de HD.
\end{abstract}

Palabras clave: Biomateriales; Vitrocerámica bioactiva; 3CaO. $\mathrm{P}_{2} \mathrm{O}_{5}-\mathrm{SiO}_{2}-\mathrm{MgO}$-system; Remineralización de dentina; Hipersensibilidad dentinaria.

\section{Introduction}

Among the most frequent dental injuries are caries (dental cavities) and, subsequently, lesions also resulting from demineralization phenomena such as erosion, abrasion, and ablation (Nascimento et al. 2020). Such lesions are consequences of the imbalance between the processes of demineralization and remineralization that occur within the oral environment (Seong et al., 2020). Dentin is a tubular, permeable, mineralized tissue which composes most part of human teeth. It is mainly formed by type I collagen fibrils, glycosaminoglycans, phosphoproteins, phospholipids and hydroxyapatite crystals. Furthermore, dentin is covered and protected by enamel and cementum. Thus, the loss of these hard tissues may expose dentin tubules and lead to dentin hypersensitivity (DH). DH is characterized by short and sharp pain in response to thermal, mechanical, tactile, evaporative, osmotic or chemical stimuli (Addy, 2002; Mantzourania \& Sharma, 2013). The diagnosis of $\mathrm{DH}$ is made by excluding any other dental disease. The main mechanism of DH is based on the hydrodynamics of oral environment. This mechanism is triggered by the movement of fluids in and out of the dentin tubules which stimulates local sensory nerves generating the short sharp pain characteristic of DH (Shiau, 2012; Bamise \& Esan, 2011; Thanatvarakorn et al., 2013).

Under health conditions, dentin is impermeable. However, in a hypersensitive state, the dentinal tubules are open and 
permeable. Therefore, an ideal treatment for dentin sensitivity should restore the original impermeability of the dentinal tubules (Kim \& Park, 2017). Current treatments for DH are mainly based on the application of lasers (Ana et al., 2012; Fornaini et al., 2020), chemical agents as insoluble precipitates in order to occlude open dentin tubules (Blatz, 2012; Farooq et al., 2015; Gallob et al., 2019), and the association between of them (Cunha et al., 2017; Bakry, 2011). The chemical agents for example potassium oxalate, potassium chloride, glutaraldehyde, resin monomers, and other materials are the main method used in commercial desensitizing dentifrices (Kulal et al., 2016; Moreira, 2018). The major drawbacks of current treatments are short-term effects or reduction in their effectiveness with time. Since the substances that provide the occlusion of open tubules are only adhered to dentin surface, they may progressively be removed by brushing, chewing and consumption of acids in daily diet (Mitchell et al., 2011). On the other hand, in recent years biomaterials have been studied as a solution for DH because of their capacity of regenerating damaged tissues by inducing dental pulp cell growth (Huang et al., 2017; Chatzistavrou et al., 2016). Therefore, substances based on biomaterials could not easily be removed and then offer a long-term solution to DH (Tirapelli et al., 2011; Seong et al. 2020).

Bioactive glasses and GC are promising biomaterials in bone regeneration and dentin remineralization, due to their similar chemical composition to bone, dentin and enamel. In these biomaterials, the presence of elements as $\mathrm{SiO}_{2}, \mathrm{Na}_{2} \mathrm{O}$, and $\mathrm{P}_{2} \mathrm{O}_{5}$ promotes the crystallization of hydroxyapatite (HA) on tooth surface which occludes open dentin tubules and stimulates enamel regeneration (Hench \& Jones, 2015; Miguez-Pacheco et al., 2015; Montazerian \& Zanotto, 2016; Croave et al., 2016). Tirapelli et al. (2010) demonstrated that one of the advantages of Biosilicate ${ }^{\circ}$, a bioactive GC, over bioactive glasses is that the former provide blunt particles which may safely be used in an oral environment, while the latter usually results in sharp and abrasive particles. However, further studies on the potential of glass-ceramics application for the treatment of DH are necessary.

Despite the fact that bioactive glass and $\mathrm{GCs}$ from the $3 \mathrm{CaO} \cdot \mathrm{P}_{2} \mathrm{O}_{5}-\mathrm{SiO}_{2}-\mathrm{MgO}$ system have bioactive properties when exposed to simulated body fluids (Daguano et al., 2013), and that bioactive GC has enhanced biocompatibility and mechanical properties due to whitlockite as its crystalline phase (Daguano et al., 2012), it is still necessary to evaluate the behavior of such materials on demineralized dentin in order to treat $\mathrm{DH}$.

The aim of this paper is to evaluate a whitlockite GC based on the $3 \mathrm{CaO} \mathrm{P}_{2} \mathrm{O}_{5}-\mathrm{SiO}_{2}-\mathrm{MgO}$ system and its bioactive parent glass regarding the occlusion of human dentin in order to treat DH. In addition, this study proposes a different tool for investigating the dentinal remineralization, i.e. a semi-quantitative compositional analysis was performed using Attenuated Total Reflection of Fourier Transform Infrared Spectroscopy (ATR-FTIR) (Bakry, 2007). Though this spectroscopy technique is often applied for the chemical characterization of biomaterials, since it is an effective nondestructive technique, SEM is considered the most important tool to evaluate DH treatments (Ma et al., 2017; Tunar et al., 2014).

\section{Methodology}

\subsection{Glass synthesis and characterization}

Bioactive glass with nominal composition $52.75\left(3 \mathrm{CaO}^{2} \mathrm{P}_{2} \mathrm{O}_{5}\right)-30 \mathrm{SiO}_{2}-17.25 \mathrm{MgO}$ (wt.\%) was prepared from highpurity reagent-grade $\mathrm{Ca}\left(\mathrm{H}_{2} \mathrm{PO}_{4}\right)_{2}, \mathrm{CaCO}_{3}, \mathrm{SiO}_{2}$ and $\mathrm{MgO}$. Batches were obtained by mixing the raw materials in ethanol for $240 \mathrm{~min}$, drying at $90{ }^{\circ} \mathrm{C}$ for $24 \mathrm{~h}$ and passing it through a sieve with openings of $64 \mu \mathrm{m}$ for deagglomeration. The glass was prepared according to the conventional melting method in a platinum crucible at $1600{ }^{\circ} \mathrm{C}$ using a $\mathrm{MoSi}_{2}$ furnace model F-1650 (Maitec, Brazil) (Daguano et al., 2013). In order to obtain whitlockite glass-ceramic (GC), the aforementioned bioactive glass was further double-stage heat-treated at $700{ }^{\circ} \mathrm{C}$ and $775{ }^{\circ} \mathrm{C}$ for $4 \mathrm{~h}$ and cooled down at a rate of $3{ }^{\circ} \mathrm{C} / \mathrm{min}$, using an EDG-7000 - Furnace (EDG, Brazil). Also, a cast bioactive glass 45S5 with chemical composition 45SiO${ }_{2}-24.5 \mathrm{Na}_{2} \mathrm{O}-24.5 \mathrm{CaO}-6 \mathrm{P}_{2} \mathrm{O}_{5}$ (wt.\%) was prepared from high-purity reagent-grade $\mathrm{Na}_{2} \mathrm{HPO}_{4} ; \mathrm{CaCO}_{3} ; \mathrm{SiO}_{2}$ and $\mathrm{Na}_{2} \mathrm{CO}_{3}$. All samples were crushed and 
sieved to a particle size smaller than $32 \mu \mathrm{m}$.

The structure of the glasses and GC was confirmed by powder X-ray diffraction using a diffractometer (D8 Focus, Bruker, Germany) with a monochromatic X-ray beam of $\mathrm{Cu}-\mathrm{K} \alpha(\lambda=1,5406 \AA)$. The powders were analyzed under diffraction angles ranging from $10^{\circ}$ to $50^{\circ}$, with a step size of $0.02^{\circ}$, and a counting time of $1 \mathrm{~s}$ per step.

SEM images were also used to examine the morphology of the edge of the particles from the biomaterials investigated in this study. The latter was carried out by a scanning electron microscope (Quanta 250, FEI, USA). The powders were fixed on stubs with a carbon tape and underwent sputtering prior to SEM. Then, they were analyzed by ImageJ software to measure the angle of the edges of particles. Such measurements were performed by "angle tool".

\subsection{Preparation of dentin discs}

Forty extracted non-carious third human molars were obtained from the Human Teeth Bank of School of Dentistry of University of São Paulo - Brazil. This study was approved by the Ethics Committee for the Use of Animals of the Federal University of ABC (CEUA-UFABC), process number 1.417.062, and was carried out with the observance of the procedures required by this same committee.

In vitro occlusion of dentinal tubules was investigated using the dentin disc model. Forty 3 × 3 x $1 \mathrm{~mm}$ discs were prepared, from the occlusal surface of the teeth, using a water-cooled diamond saw. Afterwards, the occlusal surface of each dentin disc was sanded with silicon carbide paper and polished with diamond paste in order to create a standard smear layer. The smear layer was subsequently removed by dipping the dentin discs into $0.5 \mathrm{M}$ EDTA (ethylenediaminetetracetic acid) solution ( $\mathrm{pH}$ 7.4) for 5 minutes. Then, the etched discs were rinsed for 2 minutes to assure complete removal of the EDTA solution.

\subsection{Occlusion of dentinal tubules}

After EDTA etching, the dentin discs were randomly distributed into four experimental groups $(n=10)$ :

Group 1 (NT): Negative control (no treatment).

Group 2 (BG): Positive control (treated with Bioglass ${ }^{\circledR} 45 \mathrm{~S} 5$ ).

Group 3 (GL): Treatment with a bioactive glass based on $3 \mathrm{CaO} . \mathrm{P}_{2} \mathrm{O}_{5}-\mathrm{SiO}_{2}-\mathrm{MgO}$-system.

Group 4 (WGC): Treatment with a whitlockite GC.

The biomaterials were applied to the dentin surfaces, following the classification previously described, by spreading $0.2 \mathrm{~g}$ of each one mixed with distilled water immediately before application for $60 \mathrm{~s}$ using cotton swabs. Then the discs were lightly washed with distilled water. Afterwards, all the samples were stored in $20 \mathrm{~mL}$ of artificial saliva, at controlled temperature of $37^{\circ} \mathrm{C}$ for 7 days, to induce remineralization. It is important to highlight that artificial saliva was replaced every day. Table 1 presents the chemical composition of artificial saliva. 
Table 1 - Composition of the artificial saliva used to induce dentin remineralization.

\begin{tabular}{|c|c|c|}
\hline Reagent & Manufacturer & Quantity \\
\hline $\mathrm{Ca}\left(\mathrm{NO}_{3}\right)_{2} \cdot 4 \mathrm{H}_{2} \mathrm{O}$ & Sigma-Aldrich, MO, EUA & $1.5 \mathrm{mM}$ \\
\hline $\mathrm{H}_{2} \mathrm{NaPO}_{4} \cdot \mathrm{H}_{2} \mathrm{O}$ & Sigma-Aldrich, MO, EUA & $0.9 \mathrm{mM}$ \\
\hline Fluoride Standard & Orion, EUA & $0.03 \mathrm{ppm}$ \\
\hline $\mathrm{KCl}$ & Sigma-Aldrich, MO, EUA & $150 \mathrm{mM}$ \\
\hline TRIS & Sigma-Aldrich, MO, EUA & $0.1 \mathrm{M}$ \\
\hline
\end{tabular}

Source: Authors.

All quantities informed in Table 1 were used for the preparation of $1 \mathrm{~L}$ of artificial saliva. Solutions of $20 \% \mathrm{NaOH}$ and $20 \% \mathrm{HCl}$ were added to artificial saliva solution to reach its functional $\mathrm{pH}(\mathrm{pH} 5.0)$.

\subsection{Characterization of dentin samples}

After the treatments with the aforementioned biomaterials, all the dentin samples had their chemical composition evaluated by Attenuated Total Reflection technique of Fourier Transform Infrared Spectroscopy (ATR-FTIR), using a FTIR 640-IR (Varian, Agilent, USA), operating in absorbance mode with 80 scans, at a resolution of $4 \mathrm{~cm}^{-1}$ and in the range of 1800 to $650 \mathrm{~cm}^{-1}$. For a semi-quantitative analysis, firstly, spectra of the samples were checked for appearance of new bands and changes in the height of band peaks. The peak heights were performed after a vetorial normalization of each spectrum using the OriginPro® 8 (OriginLab Corp., USA) software program. Secondly, the areas under the considered bands were calculated after normalization by the area of phosphate band (1300-900 $\left.\mathrm{cm}^{-1}\right)$ using the OriginPro® software again. The statistical analysis was performed individually for each band (one-way ANOVA + Tukey's test), considering each group as a separate block.

The dentin samples were also examined by a Scanning Electron Microscope (Quanta 250, FEI, USA). The samples were fixed on stubs with carbon tape, but sputtering was not performed.

\section{Results}

Figure 1 shows the XRD patterns of all the biomaterials used in this study. Fig. 1(a) and (b), showed the typical amorphous halo confirming the vitreous state of the Bioglass ${ }^{\circledR} 45 \mathrm{~S} 5$ and the glass based on $3 \mathrm{CaO} . \mathrm{P}_{2} \mathrm{O}_{5}-\mathrm{SiO}_{2}-\mathrm{MgO}$-system, respectively. XRD pattern of GC (Fig. 1(c)), on the other hand, presents a halo and multiple sharp peaks which demonstrate that this material contains a crystalline phase and a residual vitreous phase. The crystalline phase of the $3 \mathrm{CaO}_{2} \mathrm{P}_{2} \mathrm{O}_{5}-\mathrm{SiO}_{2}-\mathrm{MgO}$ GC was identified as whitlockite comparing to reference patterns of JCPDS (PDF\#87-1582). 
Figure 1 - XRD patterns of (a) Bioglass ${ }^{\circledR} 45 \mathrm{~S} 5$, (b) parent glass based on 3CaO.P ${ }_{2} \mathrm{O}_{5}-\mathrm{SiO}_{2}-\mathrm{MgO}$-system (c) whitlockite GC.

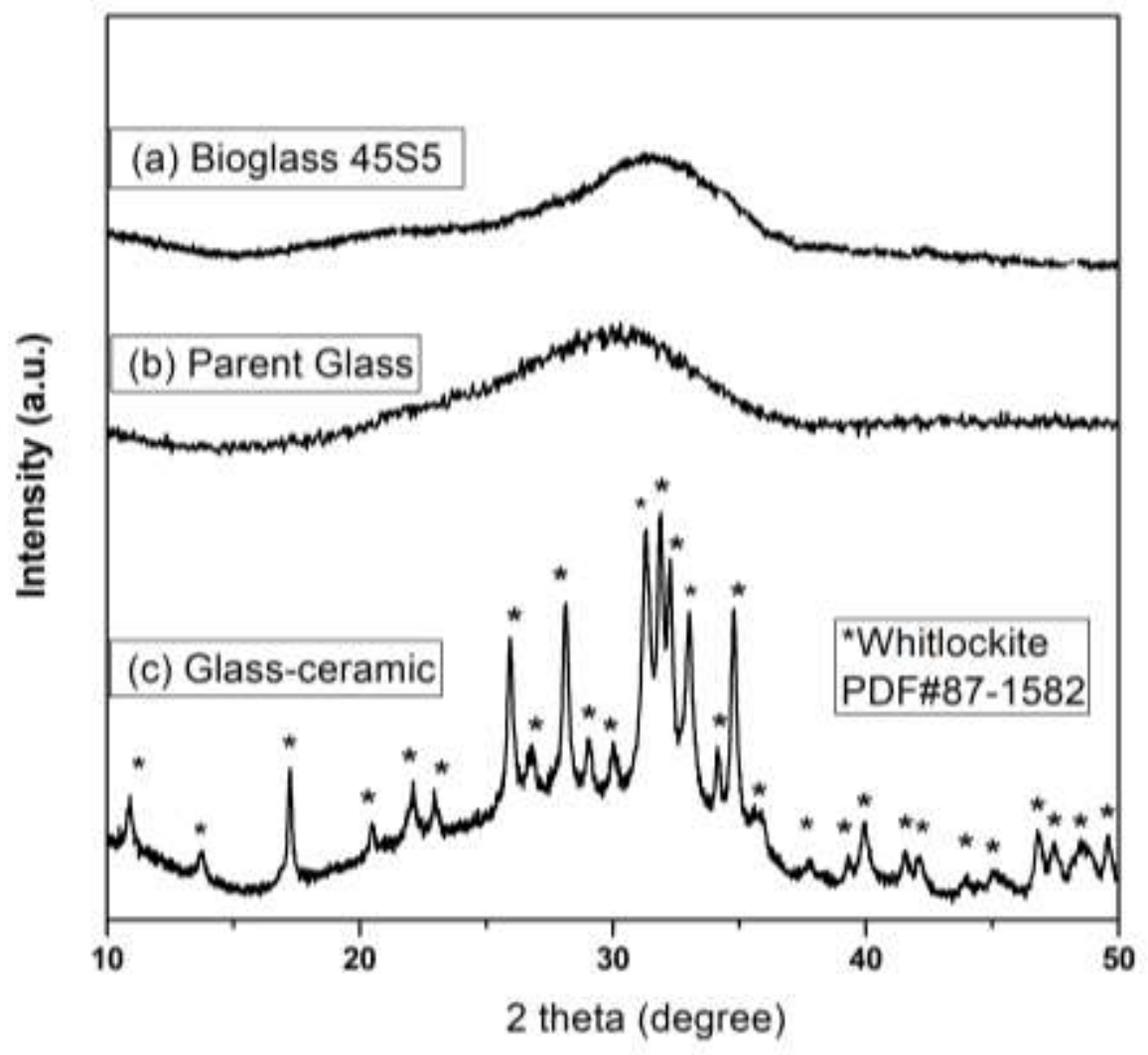

Source: Authors.

Figure 2 exhibits SEM images of the samples in powder form. As can be observed in Figure 2(a) and (b), the particles from both of the glasses are sharp-edged, whereas the ones from the GC are round-edged, Figure 2(c). 
Figure 2 - SEM images of the powders from (a) Bioglass®45S5, (b) parent glass and (c) whitlockite GC. Original magnification: 5,000x.

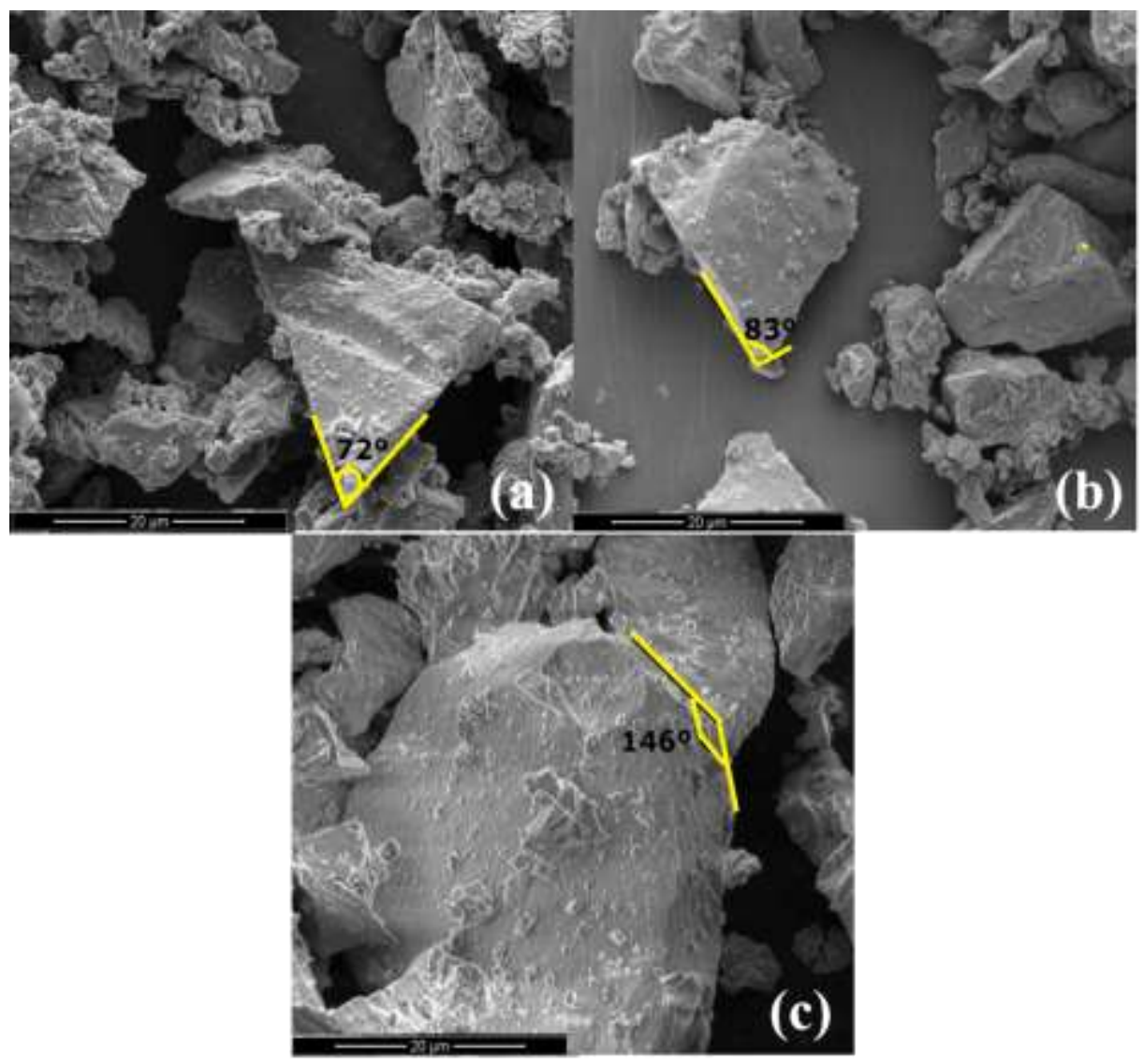

Source: Authors.

As previously described, several SEM micrographs were used to measure the edge angles of some particles from each biomaterial. At least ten images were considered to obtain a statistical analysis. Table 2 summarizes the measurements of the edge angles.

Table 2 - Measurements of the edge angles of some particles from each biomaterial.

\begin{tabular}{|c|c|c|c|}
\hline Material & Bioglass $^{\circledast}$ 45S5 & Parent glass & Whitlockite GC \\
\hline Edge angles & $90^{\circ} \pm 13^{\circ}$ & $89^{\circ} \pm 10^{\circ}$ & $122^{\circ} \pm 15^{\circ}$ \\
\hline
\end{tabular}

Source: Authors.

According to the data presented by Table 2, there is a distribution of values of the edge angles for each biomaterial. Nevertheless, the edges of the particles from both of the glasses tend to be acute and sharp, since the average values of the edge angles are $90^{\circ} \pm 13^{\circ}$ and $89^{\circ} \pm 10^{\circ}$ for Bioglass ${ }^{\circledR} 45 \mathrm{~S} 5$ and for the parent glass based on $3 \mathrm{CaO}^{\circ} \mathrm{P}_{2} \mathrm{O}_{5}-\mathrm{SiO}_{2}-\mathrm{MgO}$, respectively. The particles from the whitlockite GC, alternatively, tend to exhibit obtuse edge angles (an average of $122^{\circ} \pm 15^{\circ}$ ) which lead to round and blunt edges.

The dentin samples were investigated by FTIR, in terms of their chemical composition. Figure 3 illustrate the ATRFTIR spectra of healthy dentin and EDTA-etched dentin (Fig. 3a), and all the experimental groups (Figure 3b). 
Figure 3 - ATR-FTIR spectra obtained from: (a) healthy dentin and EDTA-etched dentin, and (b) all the experimental groups: G1-NT, G2-BG, G3-GL and G4-WGC.

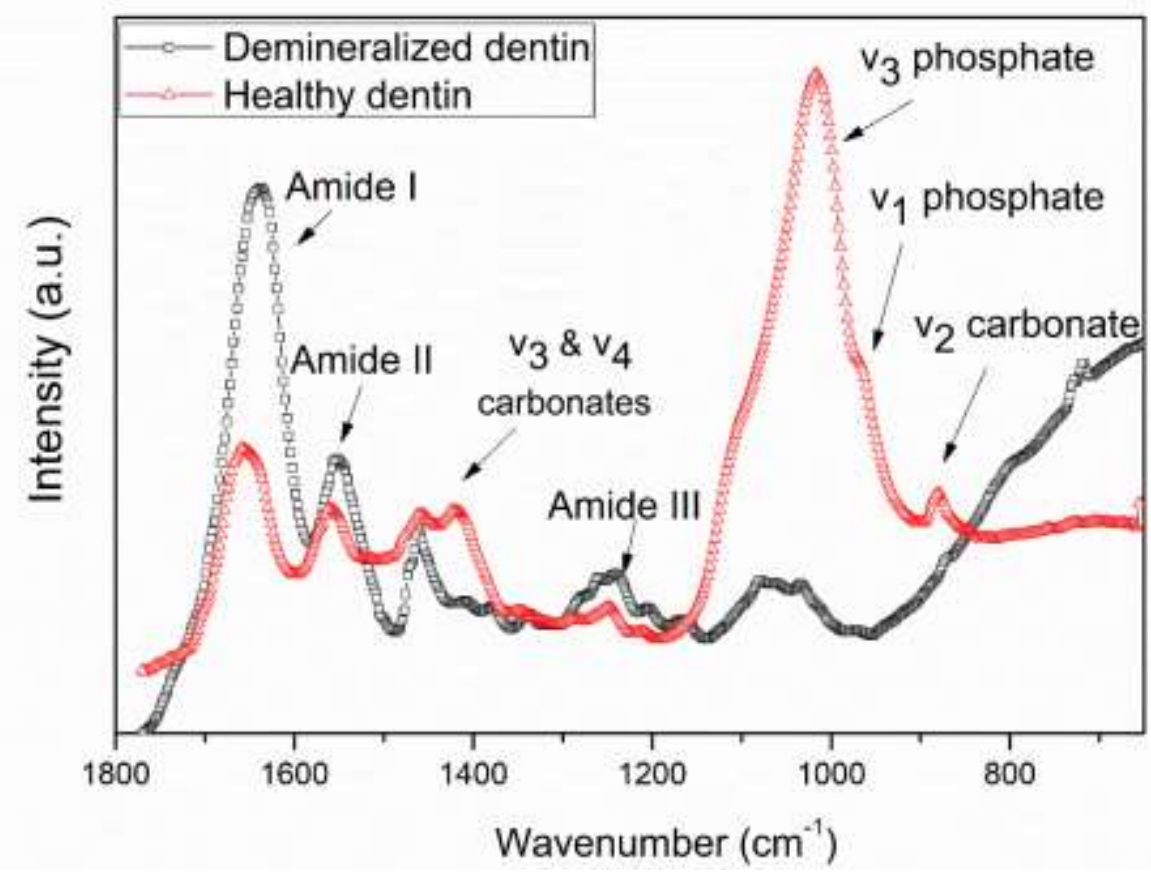

(a)

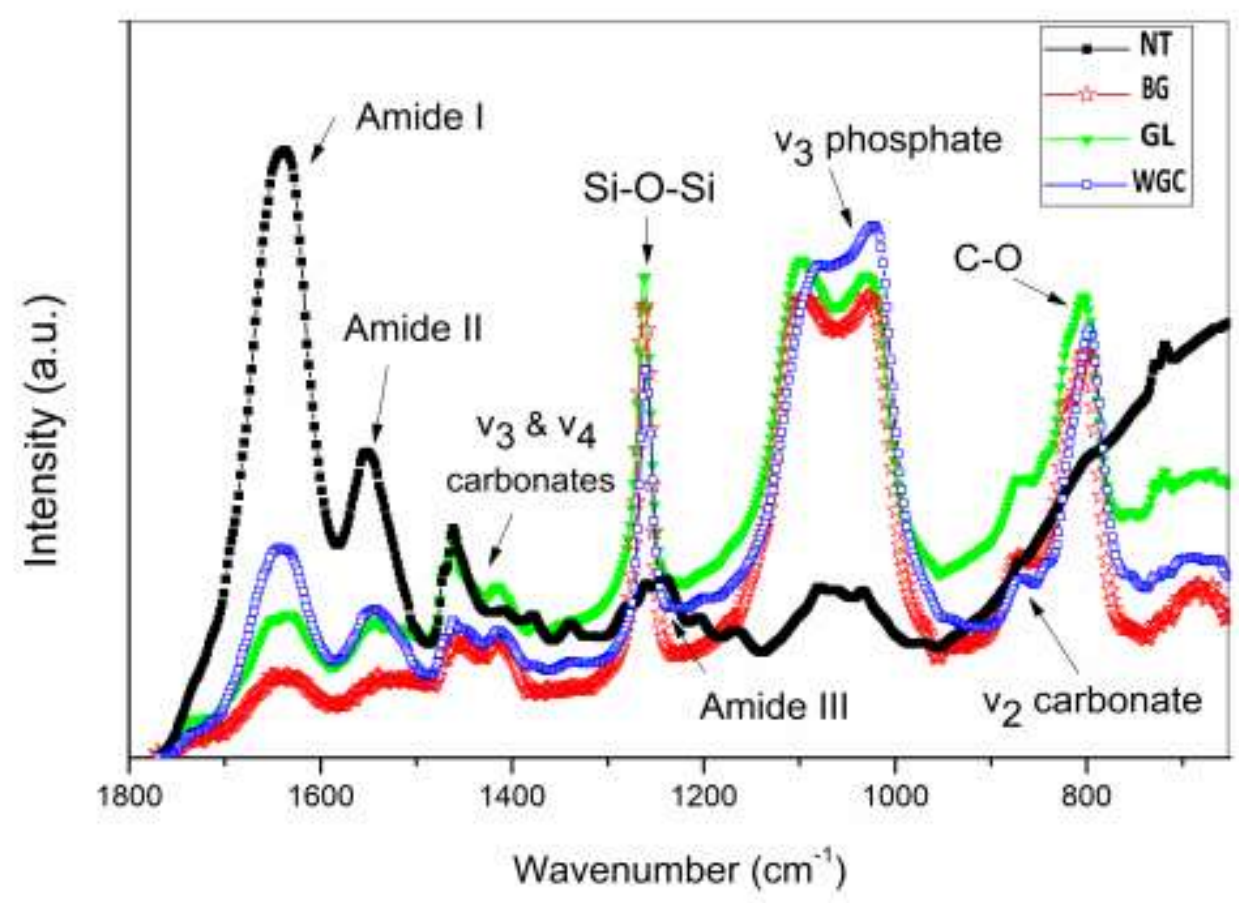

(b)

Source: Authors.

FTIR spectra shown in Figure 3(a) indicates that healthy dentin is composed basically of organic (amides I, II and III) and inorganic compounds (carbonate and phosphate). It is also reported that dentin contains water, lipids, glycosaminoglycans and other enzyms (Mantzourania \& Sharma, 2013; Shiau, 2012). After demineralization, a decrease in the intensity of phosphate and carbonate bands, as well as an increase in the intensity of amides I, II and III bands can be noted. 
Figure 3(b) displays the ATR-FTIR spectra of the EDTA-etched dentin without any treatment (NT) and after treatment with biomaterials (BG, GL, WGC). Note that the proposed treatments promoted a change in the intensity of the existing bands, and the appearance of new infrared band was observed. In the NT dentin, the characteristic peaks of amide (I, II) groups were more evident, which should be attributed the organic collagen fibrils. After treatments, the peaks of $\mathrm{v}_{3}$ phosphate and carbonates $\left(\mathrm{v}_{2}, \mathrm{v}_{3}, \mathrm{v}_{4}\right)$ groups were all significantly enhanced, which should be attributed to inorganic HA. Besides, the characteristics peak of HCA appeared.

For semi-quantification, the areas under the considered bands were calculated after tracing the baseline, and normalization was done by subtracting the area of the considered bands by the area of the phosphate band. The results of the semi-quantitative analysis of the ATR-FTIR spectra are exhibited in Table 3.

Table 3 - Semi-quantitative analysis of ATR-FTIR spectra.

\begin{tabular}{|c|c|c|c|c|}
\hline \multirow{2}{*}{ Infrared bands } & \multicolumn{3}{|c|}{ Normalized area by phosphate band (a.u.) \pm standard deviation* } \\
\cline { 2 - 4 } & G1 - NT & G2 - BG & G3 - GL & G4 - WGC \\
\hline$v_{2}$ and $v_{3}$ carbonate & $1.44 \pm 0.50^{\mathrm{a}}$ & $0.064 \pm 0.01^{\mathrm{b}}$ & $0.13 \pm 0.03^{\mathrm{b}}$ & $0.21 \pm 0.11^{\mathrm{b}}$ \\
\hline amide I & $9.32 \pm 4.97^{\mathrm{a}}$ & $0.036 \pm 0.01^{\mathrm{b}}$ & $0.20 \pm 0.07^{\mathrm{b}, \mathrm{c}}$ & $0.28 \pm 0.12^{\mathrm{c}}$ \\
\hline amide II & $1.46 \pm 0.73^{\mathrm{a}, \mathrm{c}}$ & $0.004 \pm 0.00^{\mathrm{b}}$ & $0.04 \pm 0.02^{\mathrm{b}, \mathrm{c}}$ & $0.03 \pm 0.02^{\mathrm{c}}$ \\
\hline amide III & $1.06 \pm 0.40^{\mathrm{a}}$ & $0.131 \pm 0.01^{\mathrm{b}}$ & $0.11 \pm 0.01^{\mathrm{b}}$ & $0.11 \pm 0.01^{\mathrm{b}}$ \\
\hline
\end{tabular}

*Distinct letters mean statistically significant differences according to Tukey’s test. Source: Authors.

Table 3 shows a significant decrease $(\mathrm{p}<0.05)$ on carbonate-to-phosphate ratio in BG, GL and WGC, which indicates a significant amount of phosphate formation. It was not observed any statistical differences among these same groups, which suggests that all the treatments provided equivalent amounts of hydroxyapatite on dentin. Also, Bioglass ${ }^{\circ} 45 \mathrm{~S} 5$ and parent glass demonstrated similar performances, since there are any statistical differences between BG and GL groups regarding to the quantities of amides I, II and III. The ratio between amides I, II and III and phosphate indicates the proportion of collagen to hydroxyapatite, respectively. According to the data available in Table 3, a significant decrease in this proportion was observed in BG, GL and WGC in comparison to NT.

SEM was used to observe surface morphologies of dentine discs treated in each experimental group. 
Research, Society and Development, v. 10, n. 3, e19610313161, 2021

(CC BY 4.0) | ISSN 2525-3409 | DOI: http://dx.doi.org/10.33448/rsd-v10i3.13161

Figure 4 - Surface morphologies of treated dentine samples within each experimental group. G1 - NT: EDTA-etched dentin (a) and (e) images; G2 - BG: Bioglass®45S5 (b) and (f) images; G3 - GL: parent glass (c) and (g) images; G4 - WGC: whitlockite GC (d) and (h) images. Original magnification: (a-d) 500x, (e-h) 2,000x. White arrows indicate open dentinal tubules.

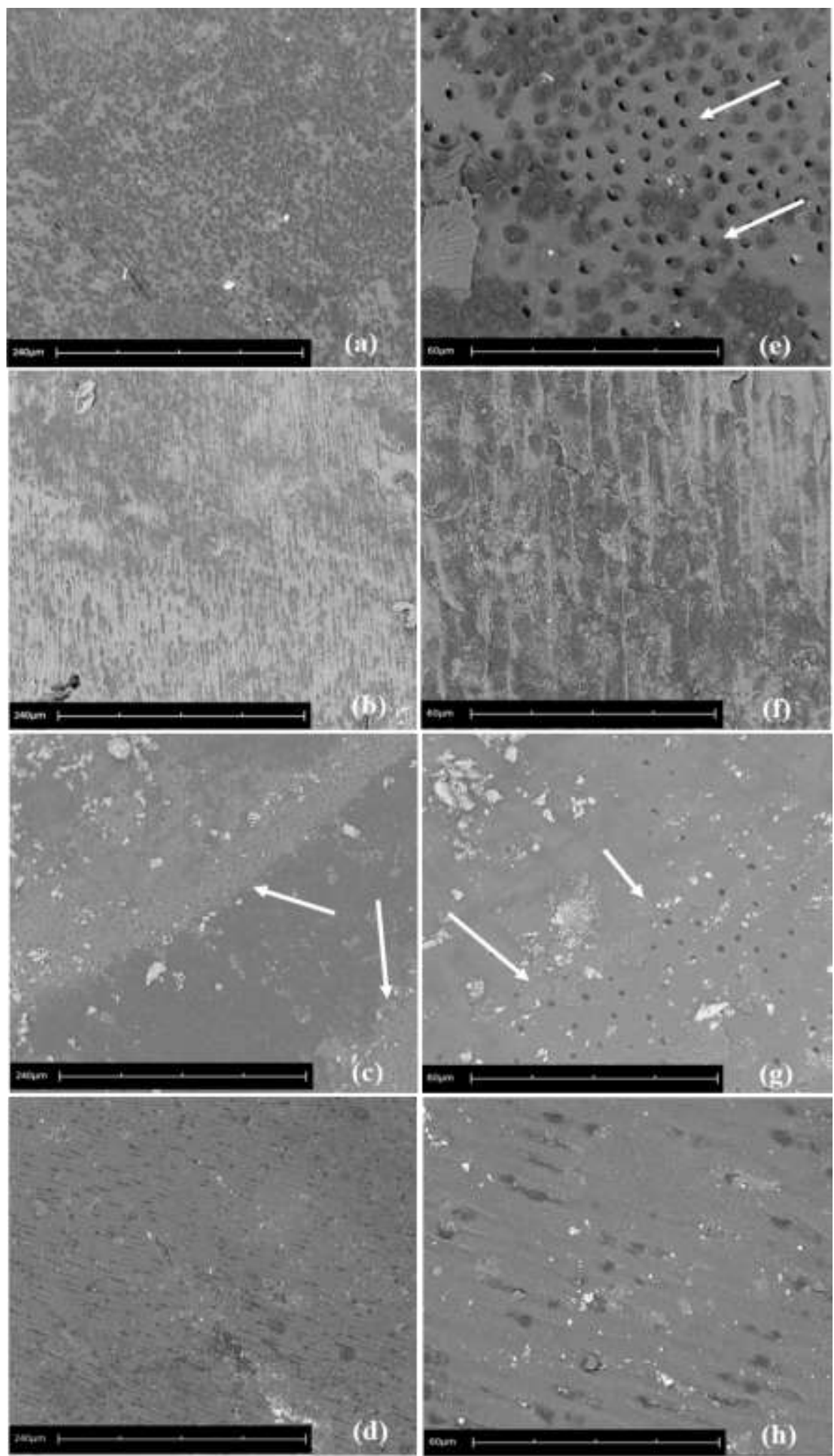

Source: Authors.

After the demineralization promoted by EDTA etching (NT samples), nearly all dentine tubules were completely 
open, due to eroded dentine discs (Figure $4 \mathrm{a}$, e). Smear layer was not observed. However, some tubules were observed partially occluded because they were immersed in artificial saliva for 7 days, as reported by Zong et al. (2015). Mineral salts from saliva may create crystal precipitates on the dentine surface, thereby decreasing the exposure of the dentinal tubules (Tunar et al., 2014).

The dentinal tubules are completely occluded in BG and WGC samples, as evidenced in Figure 4 (b,f), and 4 (d,h), respectively. On the other hand, GL samples treated with parent glass and storage in artificial saliva produced irregular crystallike deposits that covered the dentine surface and occluded dentine tubules, but allowing only a few dentine tubules remaining open, as indicated by white arrows in Figure 4 (c, g).

\section{Discussion}

Dentin hypersensitivity, DH, is a common clinical condition caused by the exposition and opening of dentin tubules (Bamise \& Esan, 2011). The use of bioactive glasses has been suggested as a promising alternative, since these biomaterials can provide the regeneration of hard tissues due to the formation of hidroxycarbonate apatite (HCA) (Wang et al., 2014; Gondim et al., 2020). However, it is necessary to evaluate the efficacy of some biomaterials, such as the ones from the $3 \mathrm{CaO} . \mathrm{P}_{2} \mathrm{O}_{5}-\mathrm{SiO}_{2}-\mathrm{MgO}$ system - whitlockite GC and its parent glass - on demineralized dentin. It was hypothesized that whitlockite GC would occlude dentine tubules as effectively as Bioglass®45S5.

The presence of the whitlockite phase can improve the bioactivity of parent glass. This phase is a tricalcium phosphate with magnesium in solid solution, also known as $\beta$-TCMP. Moreover, whitlockite enhances other mechanical properties such as bending strength and hardness. Such findings are compatible with the ones reported by Daguano et al. (2013). These results confirm that the double-stage heat-treatment of parent glass was satisfactorily designed.

It is worthwhile to note that there is a link between the shape of the edges of the particles and the structural properties of materials. The shape of the edges of the particles, shown in Figure 2, is related to the mechanisms of fracture in materials and are affected by the existence of vitreous and crystalline phases. The SEM images shown in Figure 2 support the tendencies demonstrated by the data provided in Table 2. Such difference of edge shape between bioactive glasses and GCs may be attributed to the presence of a crystalline phase, as whitlockite, which acts as a toughening agent (Peitl et al., 2012). Particularly, the acicular whitlockite causes crack-deflection leading to the formation of blunt particles. In this way, materials composed of blunt particles are considered safer for dental use (Apel et al., 2008), in comparison to sharper ones, because they could prevent micro-cuts in an oral environment which cause some discomfort to the patient (Tirapelli et al., 2011).

Regarding FTIR study, subsection 3.2, as previously mentioned, demonstrates the effect of demineralization in dentin. When dentinal tubules are opened, DH can occur. In this sense, removing the smear layer from the dentin was possible to obtain a relatively realistic physiological environment similar to what is associated with the traditional dentinal tubule exposure model (Suge et al., 2008). The FTIR spectra of NT samples demonstrate that EDTA is effective as a demineralizing agent for dentin, as described by Song et al. (2018). In contrast, BG, GL and WGC present higher quantities of phosphate, at 1016 and $1097 \mathrm{~cm}^{-1}$, and carbonate, at $875 \mathrm{~cm}^{-1}$, when compared to the spectra of NT. It might be noted that the presence of phosphate is an evidence of HCA formation and its similarity with the bone and dentin promotes the material biocompatibility (Peitl et al., 1996). Furthermore, the suppression of the amide peaks and the formation of phosphate and carbonate in the samples of BG, GL and WGC are evidences that a crystalline material, such as HCA, was formed on dentin surface and it covers the entire organic matrix exposed by EDTA-etching, as will show Figure 4. Other evidence that HCA formation occurred on the surface of dentin is the stretching of C-O bonds, at $800 \mathrm{~cm}^{-1}$, which is related to its crystalline structure (Peitl et al., 1996). Also, it has been reported that the exposed amino groups of dentinal collagen, due to demineralization with strong decalcifying agents such as EDTA, can bond chemically to dental materials (Tartari et al., 2018). Therefore, it is worth to 
mentioning that $\mathrm{Si}-\mathrm{O}-\mathrm{Si}$ bond takes place in the same region as amide III (Peitl et al., 1996) which is related to the affinity of glass for collagen (Tirapelli et al., 2011).

For ATR-FTIR analysis, the size and roughness of test particles influenced the peak heights of the infrared spectra, then direct quantitative comparison based on the height of each peak was not reliable (Zezell et al., 2010; Bakry, 2007). Based on this information, a relative comparison between peak ratios was carried out instead. The absorption bands considered for this study were phosphate $\left(1200-900 \mathrm{~cm}^{-1}\right)$, which is the major inorganic components of dentin, the $v_{2}$ vibration mode of carbonate (around $870 \mathrm{~cm}^{-1}$ ), the superposition of the stretching $v_{3}$, and bending $v_{4}$ vibration mode of carbonate (1500-1300 $\mathrm{cm}^{-1}$ ), which is one of the minor inorganic components of dentin, as well as the bands that correspond to the organic matrix of dentin-amide I $\left(1680-1600 \mathrm{~cm}^{-1}\right)$, amide II (1580-1480 $\left.\mathrm{cm}^{-1}\right)$, and amide III $\left(1200-1300 \mathrm{~cm}^{-1}\right)$.

The intensity of phosphate and carbonate bands decreased whereas the intensity of amides I, II and III bands increased. This behavior was quantified by the amide III/phosphate ratio of NT group (Table 3). The loss of phosphate leads to the exposition of dentinal tubules, which is one of the causes of DH (Shiau, 2012). A notable result of this study is the similarity between Bioglass $® 45 \mathrm{~S} 5$ and whitlockite glass-ceramic in regard to their surface reactivity. Such similarity is demonstrated by the proximity of the values corresponding to the area of phosphate and carbonate bands.

SEM images demonstrated the occlusion of dentinal tubules which is the main mechanism of treating DH (Tartari et al., 2018. Seong et al., 2020). Such findings are compatible to the ones of compositional analysis by ATR-FTIR in regard to the remineralization of dentin surface. Application of Bioglass $® 45 \mathrm{~S} 5$ and whitlockite GC to these dentine discs prior to storage in artificial saliva created granular deposits both on the surface and inside tubules completely covered the dentine surface.

In the present study, the novel bioactive GC was effective in increasing dentine occlusion. Whitlockite GC can be compared positively with the desensitizing effect of Bioglass®45S5. It might also be noted this statement is in agreement with that found earlier by Daguano et al. (2013). Although whitlockite GC and parent glass can be considered bioactive, the GC presented the most interesting result, because the onset for HCA formation is at about $24 \mathrm{~h}$, instead of 5 days for the glass.

\section{Conclusion}

The bioactive whitlochite GC from the $3 \mathrm{CaO}_{2} \mathrm{P}_{2} \mathrm{O}_{5}-\mathrm{SiO}_{2}-\mathrm{MgO}$ system succeeded in occluding dentinal tubules by promoting the formation of hidroxycarbonate apatite (HCA) on the surface of demineralized dentin, in a way very similar to the one of Bioglass $\AA^{4}$ SS5. In order to continue the work, the interaction of biomaterial with lasertherapy will be evaluated. Therefore, this biomaterial has a high potential for a future clinical application as a treatment of dentin hypersensitivity.

\section{Acknowledgments}

The authors are grateful to the Multiuser Central Facilities of the Federal University of ABC for experimental support. Daguano is thankful to the Vitreous Materials Laboratory at the Federal University of São Carlos for the donation of Biosilicate. This work was financed by the granting of scholarships by UFABC and Capes, with funds from the São Paulo Research Foundation (FAPESP) project nº 17 / 21887-4, PROCAD-CAPES (88881.068505 / 2014-01), and National Photonics Institute (CNPq / INCT 465763 / 2014-6).

\section{References}

Addy, M. (2002). Dentine hypersensitivity: new perspectives on an old problem. International Dental Journal, 52, 367-375.

Ana, P. A., Tabchoury, C. P., Cury, J. A., \& Zezell, D. M. (2012). Effect of Er,Cr:YSGG laser and professional fluoride application on enamel demineralization and on fluoride retention. Caries Research, 46(5), 441-51. 
Apel, E., Deubener, J., Bernard, A., Holand, M., Muller, R., Kappert, H., Rheinberger, V., \& Holland W. (2008). Phenomena and mechanisms of crack propagation in glass-ceramics. Journal of Mechanical Behavior of Biomedical Material, 1(4), 313-325.

Bakry, A .S., Sadr, A., Takahashi, H., Otsuki, M., \& Tagami, J. (2007). Analysis of Er:YAG Laser Dentin using Attenuated Total Reflectance Fourie Transform Infrared and X-ray Diffaction Techniques. Dental Material Journal, 26(3), 422-428.

Bakry, A .S., Takahashi, H., \& Otsuki, M. (2011). CO2 Laser Improves 45S5 Bioglass Interaction with Dentin. Journal of Dental Research, 90(2), 246-250.

Bamise, C. T., \& Esan, T. A. (2011). Mechanisms and treatment approaches of dentine hypersensitivity: a literature review. Oral Health Preventive Dentistry, $9(4), 353-67$.

Blatz, M.B. (2012). Laser Therapy may be Better Than Topical Desensitizing Agents for Treating Dentin Hypersensitivity. Journal of Evid-Based Dental Practice, 12(2), 69-70.

Chatzistavrou, X., Rao, R. R., \& Caldwell, D. J. (2016). Collagen/fibrin microbeads as a delivery system for Ag-doped bioactive glass and DPSCs for potential applications in dentistry. Journal of Non-Crystalline Solids, 432(15A), 143-149.

Crovace, M. C., Souza, M. T., \& Chinaglia, C. R. (2016). Biosilicate® - A multipurpose, highly bioactive glass-ceramic. In vitro, in vivo and clinical trials. Journal of Non-Crystalline Solids, 432, 90-110.

Cunha, S. R., Garófalo, S.A., Scaramucci, T., Zezell, D. M., \& Aranha, A. C. C. (2017). The association between Nd:YAG laser and desensitizing dentifrices for the treatment of dentin hypersensitivity. Lasers Medicine Science, 32, 873-880.

Daguano, J. K. M. F., Rogero, S. O., Crovace, M. C., Peitl, O., Strecker, K., \& Santos, C. (2013). Bioactivity and Cytotoxicity of Glass and Glass Ceramics Based on the 3CaO.P2O5-SiO2-MgO System. Journal of Materials Science: Materials in Medicine, 24, $2171-2180$.

Daguano, J. K. M. F., Strecker, K., Ziemath, E. C., Rogero, S. O., Fernandes, M. H. V., \& Santos, C. (2012). Effect of partial crystallization on the mechanical properties and cytotoxicity of bioactive glass from the 3CaO.P2O5-SiO2-MgO system. Journal of Mechanical Behavior of Biomedical Material, 14, 78-88.

Farooq, I., Moheet, I. A., \& AlShwaimi, E. (2015). In vitro dentin tubule occlusion and remineralization competence of various toothpastes. Archives of Oral Biology, 60, 1246-1253.

Fornaini, C., Brulat-Bouchard, N., Medioni, E., Zhang, S., Rocca, J., Merigo, E. (2020) Nd:YAP laser in the treatment of dentinal hypersensitivity: An ex vivo study. Journal of Photochemistry and Photobiology B: Biology, 203, 111740.

Gallob, J., Ling, M. R., Amini, P., Patil, A., Atassi, M. (2019). Efficacy of a dissolvable strip with calcium sodium phosphosilicate (NovaMin®) in providing rapid dentine hypersensitivity relief. Journal of Dentistry: X, 2, 100003.

Gondim, A. L. M. F., Barbosa, G. A. S., Dantas, W. R. M., Dantas, E. M., Oliveira, H. T. R. de ., Almeida Neto, L. F. de, Marcelino, K. P., \& Pagnoncelli, R. M. . (2020). Effect of laser therapy on osteogenesis in skullcap defects filled with $\alpha$-TCP cement and $\beta$-TCP/HA granules: animal model. Research, Society and Development, 9(10), e6889109061.

Hench, L.L., \& Jones, J.R. (2015). Bioactive Glasses: Frontiers and Challenges. Frontiers in Bioengineering Biotechnology, 3 , 194.

Huang, M., Hill, R.G., \& Rawlinson, S.C.F. (2017). Zinc bioglasses regulate mineralization in human dental pulp stem cells. Dental Materials, 33(5), 543-552.

Kim, J., \& Park, J. Dentin hypersensitivity and emerging concepts for treatments. (2017). Journal of Oral Bioscience, 59, $211-217$.

Kulal, R., Jayanti, I., Sambashivaiah, S., \& Bilchodmath, S. (2016). An In-vitro Comparison of Nano Hydroxyapatite, Novamin and Proargin Desensitizing Toothpastes - A SEM Study. Journal of Clinical and Diagnostic Research, 10(10), ZC51-ZC54.

Ma, Q., Wang, T., Meng, Q., Xu, X., Wu, H., Xu, D., \& Chen, Y. (2017). Comparison of in vitro dentinal tubule occluding efficacy of two different methods using a nano-scaled bioactive glass-containing desensitising agent. Journal of Dentistry, 60, 63-69.

Mantzourania, M., \& Sharma, D. (2013). Dentine sensitivity: Past, present and future Journal of Dentistry, 41(4), s3-s17.

Miguez-Pacheco, V., Hench, L.L., \& Boccaccini, A.R. (2015). Bioactive glasses beyond bone and teeth: Emerging applications in contact with soft tissues. Acta Biomaterialia, 13, 1-15.

Mitchell, J.C., Musanje, L., \& Ferracane, J.L. (2011). Biomimetic dentin desensitizer based on nano-structured bioactive glass. Dental Material, 27, 386-393.

Montazerian, M., \& Zannoto E.D. (2016). History and trends of bioactive glass-ceramics. Journal of Biomedical Material Research Part A, $104,1231-1249$.

Moreira, M. M., Silva, L. R. R., Mendes, T. A. D, Santiago, S. L., Mazzetto, S. E., Lomonaco, D., \& Feitosa, V. P. (2018). Synthesis and characterization of a new methacrylate monomer derived from the cashew nutshell liquid (CNSL) and its effect on dentinal tubular occlusion. Dental Material, $34,1144-1153$.

Nascimento, M. E. S., Júnior, J. R. L. S., Lima, M. V. A., Almeida, N. M. S., Hora, S.L., \& Cabral, L.L. (2020). Etiology and treatment of dentin hyperesensitivity today: integrative review. Research, Society and Development, 9(8), e661986192.

Peitl, O., LaTorre, G. P., \& Hench. L.L. (1996). Effect of crystallization on apatite-layer formation of bioactive glass 45S5. Journal of Biomedical Material Research, 30(4), 509-14.

Peitl, O., Zanotto, E. D., Serbena, F. C., \& Hench, L. L. (2012). Compositional and microstructural design of highly bioactive P2O5-Na2O-CaO-SiO2 glassceramics. Acta Biomaterialia, 8, 321-332. 
Research, Society and Development, v. 10, n. 3, e19610313161, 2021

(CC BY 4.0) | ISSN 2525-3409 | DOI: http://dx.doi.org/10.33448/rsd-v10i3.13161

Seong, J., Newcombe, R. G., Matheson, J. R., Weddell, L., Edwards, M., \& West, N. X. (2020). A randomised controlled trial investigating efficacy of a novel toothpaste containing calcium silicate and sodium phosphate in dentine hypersensitivity pain reduction compared to a fluoride control toothpaste. Journal of Dentistry, 98, 103320.

Shiau, H. J. (2012). Dentin Hypersensitivity. Journal of Evid-Based Dental Practice, 12(3), 220-28.

Song, J., Wang, H., Yang, Y., Xiao, Z., Lin, H., Jin, L., Lin, M., Chen, F., Zhu, M., Zhao, Y., Qiu, Z., Li, Y., \& Zhang, X. (2018). Nanogels of carboxymethyl chitosan and lysozyme encapsulated amorphous calcium phosphate to occlude dentinal tubules. Journal of Materials Science: Materials in Medicine, 29, 84 95 .

Suge, T., Kawasaki, A., Ishikawa, K., Matsuo, T., \& Ebisu, S. (2008). Ammonium hexafluorosilicate elicits calcium phosphate precipitation and shows continuous dentin tubule occlusion. Dental Material, 24(2), 192-198.

Tartari, T., Bachmann, L., Zancan, R. F., Vivian, R. R., Duarte, M. A. H., \& Bramante, C. M. (2018). Analysis of the effects of several decalcifying agents alone and in combination with sodium hypochlorite on the chemical composition of dentine. International Endodhotic Journal, 51(1), e42-e54.

Thanatvarakorn, O., Nakashima, S., Sadr, A., Ikeda, M., \& Tagami, J. (2013). In vitro evaluation of dentinal hydraulic conductance and tubule sealing by a novel calcium-phosphate desensitizer Journal of Biomedical Material Research Part B. 101, 303-309.

Tirapelli, C., Panzeri, H., Lara, E. H., Soares, R. G., Peitl, O., \& Zanotto, E. D. (2011). The effect of a novel crystallised bioactive glass-ceramic powder on dentine hypersensitivity: a long-term clinical study. Journal of Oral Rehabilitation, 38(4), 253-62.

Tirapelli, C., Panzeri, H., Soares, R. G., Peitl, O., \& Zannoto, E. D. (2010). A novel bioactive glass-ceramic for treating dentin hypersensitivity. Brazilian Oral Research, 24, 381-387.

Tunar, O. L., Gursoy, H., Çakar, G., Kuru, B., Ipci, S. D., \& Yilmaz, S. (2014). Evaluation of the Effects of Er:YAG Laser and Desensitizing Paste Containing 8\% Arginine and Calcium Carbonate, and Their Combinations on Human Dentine Tubules: A Scanning Electron Microscopic Analysis. Photomedicine and Laser Surgery, 32(10), 540-545.

Wang, S., Gao, X., Gong, W., Zhang, Z., Chen, X., \& Dong, Y. (2014). Odontogenic differentiation and dentin formation of dental pulp cells under nanobioactive glass induction. Acta Biomaterialia., 10, 2792-2803.

Zhong, Y., Liu, J., Li, X., Yin, W., He, T., Hu, D., Liao, Y., Yao, X., \& Wang, Y. (2015). Effect of a novel bioactive glass-ceramic on dentinal tubule occlusion: an in vitro study. Australian Dental Journal, 60, 96-103. 